\title{
LEARNING MANAGEMENT SYSTEM AND ITS IMPLEMENTATION
}

Salman Zafar, Dr. Nabeel Tahir

\begin{abstract}
As the world is moving towards autonomous technology and every aspect of human lives is influenced by technology so does the academics and academic institutions, learning management systems work in academic institutes across the globe, this paper gives a comparison between different learning management systems and their comparative analysis, it will help any individual who wants to compare and choose the best learning management system with respect to the requirements of their institute.
\end{abstract}

\section{INTRODUCTION}

By the start of $21^{\text {st }}$ century, every single aspect of human life is moving towards technology. The advancement in technology has changed the way humans live their lives, whether we talk about industry, market or academics. In the field of academics new and innovative ways of learning are constantly produced to make human lives easier as well as boost up learning [1]. For this purpose, learning management systems are being deployed across the globe. Few of the LMS include Blackboard, Moodle and success factors.

Moodle is an open source learning management system which is based on the web platform of PHP MySQL. It offers a dynamic environment for the education sector. It is used for the number of different services in an educational institute. Few of the uses of Moodle are blended learning it provides a learning environment using different platforms as well as new and innovative ways. $E$ learning is a mechanism in which all the students are provided with an E-Learning environment where the usage of paper environment is finished from the institutes using brick and motor system [2]. Teacher Management allows the teacher to manage their classes, courses, students, to-do list as well as conduct assignments, quizzes and exams online.Student Management provides with the facility where students can download their course outlines, contents as well as upload assignments for assessment and attempt quizzes and exams. They 
are also able to communicate with their lecturers, tutors, lab attendants as well as other students. Course Management allows new courses to be structured, updated or deleted. Add new content, assignments as well as quizzes. Exam Management system provides a dynamic and wide range of exam solutions, teachers can set up an exam, conduct it as well as evaluate it. Report generation Moodle allows the Administration to generate reports to evaluate the performance of each individual including teachers and students [3].

\begin{tabular}{|l|l|l|}
\hline & \multicolumn{1}{|c|}{ Blackboard Learn(Release 9.1) } & \multicolumn{1}{c|}{ Moodle 2.0 } \\
\hline $\begin{array}{l}\text { Calendar/ } \\
\text { Progress Review } \\
\text { [3] }\end{array}$ & $\begin{array}{l}\text { Instructors and students can post events in the } \\
\text { online course calendar. } \\
\text { Instructors can post announcements to a } \\
\text { course announcement page. } \\
\text { Students have a personal home page that lists allc } \\
\text { ourses in which the student is enrolled, new } \\
\text { email and all course and system-wide events } \\
\text { from their personal calendar. } \\
\text { Students can view their grades on completed } \\
\text { assignments, total points possible, course grade, } \\
\text { and compare their grades against the class } \\
\text { performance. }\end{array}$ & $\begin{array}{l}\text { Instructors and students can post events in the } \\
\text { online course calendar. } \\
\text { Instructors can post announcements to a cours } \\
\text { ennouncement page. } \\
\text { Students have a personal home page that lists } \\
\text { all } \\
\text { courses in which the student is enrolled, new } \\
\text { email and all course and system-wide events fr } \\
\text { om their personal calendar. } \\
\text { Students can view their grades on completed } \\
\text { assignments, total points possible, course grad } \\
\text { e, } \\
\text { and compare their grades against the class } \\
\text { performance. } \\
\text { Students can subscribe to RSS feeds to be } \\
\text { notified of changes to materials. }\end{array}$ \\
\hline Searching Within & $\begin{array}{l}\text { Students can search all discussion threads } \\
\text { Course [3] }\end{array}$ & $\begin{array}{l}\text { Students can search all discussion threads. } \\
\text { Stunsion recordings. }\end{array}$ \\
\hline $\begin{array}{l}\text { Module Page } \\
\text { [2,3] }\end{array}$ & $\begin{array}{l}\text { Similar to dashboard notifications on the } \\
\text { Blackboard home page. Modules contain } \\
\text { information for instructors and students about } \\
\text { new content and due dates for the current course. }\end{array}$ & $\begin{array}{l}\text { Modules Upcoming events and recent activity } \\
\text { both displayed left hand side of the course } \\
\text { material. Can be docked as a tab to the left of } \\
\text { the page. }\end{array}$ \\
\hline
\end{tabular}




\begin{tabular}{|c|c|c|}
\hline $\begin{array}{l}\text { Community } \\
\text { Networking [3] }\end{array}$ & $\begin{array}{l}\text { If allowed, at system level, students can create } \\
\text { online clubs, interest, and study groups. These } \\
\text { groups can have their own catalog, templates, } \\
\text { discussion boards and more. }\end{array}$ & $\begin{array}{l}\text { Major focus of Moodle } 2.0 \text { allowing different } \\
\text { Moodle installations to network. Idea is for } \\
\text { instructors to be able to access a location where } \\
\text { they can share with peers - in their own topic - } \\
\text { best practice, ideas and resources. Also allow } \\
\text { users to join in with communities of practice that } \\
\text { might be hosted by other sites. The functional } \\
\text { aspect is to allow anyone to turn their Moodle site } \\
\text { into a Moodle Community Hub, with seamless } \\
\text { log-in between Moodles, but also with the login } \\
\text { secure and fully controlled by site administrators }\end{array}$ \\
\hline $\begin{array}{l}\text { Course Menu } \\
\text { [3] }\end{array}$ & Click '+' icon to access the choice list & Menu is automatically updated with links to new \\
\hline $\begin{array}{l}\text { Assignments } \\
{[2,3]}\end{array}$ & $\begin{array}{l}\text { New } 9.0 \text { - } \\
\text { Multiple attempts for submission (example } \\
\text { revisions) } \\
\text { New } 9.0 \text { - } \\
\text { Assignment submission for groups by } \\
\text { an individual. }\end{array}$ & $\begin{array}{l}\text { Assignments can be completed online or offline } \\
\text { (file uploads). Moodle allows for multiple file } \\
\text { uploads. Also assignments are treated as 'draft' } \\
\text { until the "send for submission" button pressed }\end{array}$ \\
\hline \multirow[t]{2}{*}{$\begin{array}{l}\text { Custom grading } \\
\text { view and } \\
\text { grading } \\
\text { preferences } \\
{[2,3]}\end{array}$} & $\begin{array}{l}\text { Smart view can be used and in turn made a } \\
\text { favourite making it available from the front } \\
\text { page example showing on instructor's front pag } \\
\text { e } \\
\text { students who are falling under a certain grade. }\end{array}$ & $\begin{array}{l}\text { Enhanced Gradebook in Moodle } 2.0 \text {, with } \\
\text { functionality such as assignment of personal } \\
\text { grade letters to percentages. Can also edit directly } \\
\text { in } \\
\text { spreadsheet view }\end{array}$ \\
\hline & Blackboard Learn(Release 9.1) & Moodle 2.0 \\
\hline $\begin{array}{l}\text { Group } \\
\text { Organizing } \\
{[3]}\end{array}$ & $\begin{array}{l}\text { Group created first and then modified manually } \\
\text { later to add users. Instructor can allow students } \\
\text { to create their own self-enrolled groups and edit } \\
\text { their student-created groups. }\end{array}$ & $\begin{array}{l}\text { Groups created first then group members selected } \\
\text { from list on same page. Automatic allocation } \\
\text { available. Students can also self-select groups. }\end{array}$ \\
\hline
\end{tabular}

\section{HISTORY}

Moodle was formerly developed by Martin Dougiamas to help educators create online classes with a give attention to interaction and collaborative construction of content, and it is in continuous
Figure 1.1[4]

evolution. The first version of

Moodle was released on $20^{\text {th }}$ August 2002. Nowadays the Moodle is being monitored and updated by Moodle HQ, an Australian company of developers which is supported by a network of eighty-four Moodle Partner 
service companies worldwide [5]. Moodle's development has also been assisted by the work of opensource computer programmers.

Moodle as a learning platform can boost existing learning environments. As an E-learning tool, Moodle has a variety of standard and ground-breaking features such as calendar and
Grade book. Moodle is a leading virtual learning environment and can be used in many types of environments such as education, training, and development in business settings. Following are the versions of Moodle since the start of the production till date and their added features and final product.

Table 1: Comparative analysis between different versions of Moodle

\begin{tabular}{|l|l|l|}
\hline Version & Release Date & Added Features \\
\hline 1.0 & $20-08-2002$ & Basic \\
\hline 1.1 & $29-08-2003$ & Basic \\
\hline 1.2 & $20-03-2004$ & Added logins \\
\hline 1.3 & $25-05-2004$ & Messenger \\
\hline 1.4 & $31-08-2004$ & Bulk logins \\
\hline 1.5 & $05-06-2005$ & Grade books \\
\hline 1.6 & $20-05-2006$ & Grading standards \\
\hline 1.7 & $07-11-2006$ & Calendars \\
\hline 1.8 & $30-03-2007$ & Same \\
\hline 1.9 & $03-03-2008$ & $\begin{array}{l}\text { New grade book, Bulk user actions, } \\
\text { Tagging. }\end{array}$ \\
\hline 2.0 & $24-11-2010$ & $\begin{array}{l}\text { Integration with plagiarism } \\
\text { detection/prevention tools }\end{array}$ \\
\hline 2.1 & $01-06-2011$ & $\begin{array}{l}\text { Advanced grading methods like } \\
\text { Rubrics }\end{array}$ \\
\hline 2.2 & $05-12-2011$ & Drag and drop files \\
\hline 2.3 & $25-06-2012$ & Same \\
\hline 2.4 & $03-12-2012$ & Same \\
\hline
\end{tabular}




\begin{tabular}{|l|l|l|}
\hline 2.5 & $14-05-2013$ & Badges \\
\hline 2.6 & $18-11-2013$ & $\begin{array}{l}\text { Annotate uploaded PDF, bulk course } \\
\text { creation, multiple calendars }\end{array}$ \\
\hline 2.7 & $12-05-2014$ & $\begin{array}{l}\text { ATTO HTML Editor, responsive } \\
\text { design, log in with email address, }\end{array}$ \\
\hline 2.8 & $10-11-2014$ & Text auto save, like, ratings \\
\hline 2.9 & $11-05-2015$ & Dashboard, View all grades \\
\hline 3.0 & $16-11-2015$ & 4 new quiz types \\
\hline 3.1 & $23-05-2016$ & $\begin{array}{l}\text { Competencies, recycle bin, global } \\
\text { search, support for universal office } \\
\text { converter }\end{array}$ \\
\hline 3.2 & $05-12-2016$ & $\begin{array}{l}\text { Grading improvements, auto-login, } \\
\text { sign-up improvements and SSO, } \\
\text { new notification preferences }\end{array}$ \\
\hline 3.3 & $15-05-2017$ & $\begin{array}{l}\text { PHP 5.6.5 as the minimum version } \\
\text { required, open ssl and file info } \\
\text { required, Font types available for } \\
\text { Moodle icons }\end{array}$ \\
\hline
\end{tabular}

\section{Features:}

\section{Built for learning globally}

Provides a web-based platform where user does not have to be on campus to access their accounts. They can access their courses, upload their assignments and attempt their quizzes from virtually anywhere in the world.

\section{Proven and trusted} worldwide

As Moodle is being used from a long period of time, Moodle is pioneers in creating a dynamic LMS, Provides SSL encryption in the latest version, has high security protocols and is being used in the big names of academics such as Monash University, Federation University etc.

\section{Designed to support both} teaching and learning

It is designed to create new innovative ways for teachers but still keeps the charm of traditional 
teaching styles [6]. It supports teachers in providing students with new and better ways to learn using different content as well as different perspective of study.

\section{Easy to use}

Moodle is designed to be highly user friendly, as it is developed on the platform of PHP MySQL, it is highly dynamic and customizable, so one can customize it according to the requirements of their institute.

\section{Free with no licensing fee}

Moodle is completely free open source learning management system. One doesn't have to pay to get the license.

\section{All in one learning platform}

It provides a dynamic E-learning platform, which covers the entire academic usability; Moodle is more than enough for an institute to cover all their academic needs [7].

\section{Highly flexible and fully customizable}

As it is developed on PHP MySQL, it is highly robust and fully customizable, one can customize the theme or the way it is represented and even the way it operates [8]. So, every institute customizes it with respect to their own requirements.

\section{Robust, secure and private}

It's completely private as every user has their own access account. Their accounts are secured with SSl encryption logins and it is highly secured and maintains the data in worst conditions possible.

\section{Use anytime, anywhere and on any device}

As Moodle is a web-based dynamic software, it can be accessed on laptops, IPad and any other kind of handheld devices from anywhere across the world with a simple single requirement i.e. internet.

\section{Comparative study between Moodle 2.7 and 3.2}

Given below is the comparative study and analysis of the two versions of Moodle and its features. 
Table 2: Features and versions of LMS

\begin{tabular}{|l|c|c|}
\hline Features & Version 2.7 & Version 3.2 \\
\hline Grade book & $\checkmark$ & $\checkmark$ \\
\hline Bulk user action & $\checkmark$ & $\checkmark$ \\
\hline Tagging & $\checkmark$ & $\checkmark$ \\
\hline Plagiarism detection & $\checkmark$ & $\checkmark$ \\
\hline Advanced grading & $\checkmark$ & $\checkmark$ \\
(Rubrics) & & $x$ \\
\hline Drag and drop files & $\checkmark$ & $\checkmark$ \\
\hline Badges & $\checkmark$ & $\checkmark$ \\
\hline Bulk course creation & $\checkmark$ & $\checkmark$ \\
\hline Multiple calendars & $\checkmark$ & $\checkmark$ \\
\hline HTML editor & $\checkmark$ & $\checkmark$ \\
\hline Login with email & $\checkmark$ & $\checkmark$ \\
\hline Text auto-save & $\checkmark$ & $\checkmark$ \\
\hline Likes & $x$ & $\checkmark$ \\
\hline Ratings & $x$ & $\checkmark$ \\
\hline Dashboard & $x$ & $\checkmark$ \\
\hline View all grades & $x$ & $\checkmark$ \\
\hline Recycle Bin & $x$ & \\
\hline Office converter & $x$ & \\
\hline Notification preferences & $x$ & \\
\hline Font types for icons & $x$ & \\
\hline
\end{tabular}

\section{Grade book:}

This feature provides a predefined book of grades for the evaluation of assignments, quizzes and exams of students. It provides ease for the teachers to evaluate as they have hardcoded marking key.

\section{Bulk user action:}

This feature allows users to communicate with huge number of other users directly and together, send them any notifications or share any files with everyone at the same time, it also allows a specific function to be performed 
on the number of users together at the same time [9].

\section{Tagging:}

Tagging allows any specific user to tag other users in any notification or any content they want to share with any specific individual, it can be public or private tagging.

\section{Plagiarism detection:}

This feature allows the integration of software like Turnitin, which allows both students as well as teachers to check if there is anything which is directly copied from the internet. It helps students to improve their assignments and any other documents, as well as it helps teachers to evaluate assignments and other content efficiently.

\section{Advanced grading (Rubrics):}

Parameters have become popular with teachers as a method of connecting expectations for a project, providing focused feedback on works happening and grading final products. Although teachers tend to define the word "rubric" in different ways, Heidi Andrade's commonly accepted definition is a document that articulates the expectations for a job by listing the requirements, or what counts, and describing levels of quality from excellent to poor [10].

\section{Drag and drop files:}

This feature allows a user to directly drag $\mathrm{n}$ drop the files they want to upload, it is not required to go through the messenger upload anymore.

\section{Bulk course creation:}

This is one of the most important features, it allows a user to create number of courses together, the need of creating each course separately is no more required as it is much more time consuming and less efficient.

\section{Multiple calendars:}

This allows creating a different calendar for every different course or class and adjusting their calendar accordingly. It makes to management easy for all the courses and necessary actions required to complete it on the basis of dates and months.

\section{HTML editor:}

This is one of the most important features, it allows the administrator to directly modify, update and write new features using the HTML editor. They can modify the look and feel of their 
website as well as how it operates from user's perspective.

\section{Login with email:}

This is a simple yet very important feature, it integrates users email id with the Moodle which helps the user to login to Moodle using their email address.

\section{Auto-save:}

Any work which is being done on Moodle, either it's an assignment made by student or quizzes made by teachers or any sort of information being typed or uploaded on Moodle is saved automatically.

\section{Likes:}

This feature allows users to like any comments, posts, announcements, content, courses and discussions; basically anything on Moodle is likable by its users.

\section{Ratings:}

This is a feature which allows students to rate teachers and vice versa. This allows students and teachers to evaluate their own performance, how students find their teaching style and behavior, because of this, teachers tend to work in the more efficient way to get their ratings improved.

\section{Dashboard:}

Dashboard is the front end display which gives access to all the necessary information to students as well as teachers on the front page of their Moodle.

\section{View all grades:}

Students can now access all their degree grades, detailed mark sheets, transcripts for each course, semester and the entire degree.

\section{Recycle Bin:}

Now deleted files are not permanently deleted from Moodle rather they stay in a recycle bin on Moodle which is now available as mentioned earlier.

\section{Office converter:}

Now users are able to convert their word files into PDF and other way around, it's a basic converter which allows the users to change any format of Microsoft office files.

\section{Notification preferences:}

Now users can define priority to their notifications. They can priorities it according to their own requirements.

\section{Font type for icons:}

This feature allows the administrator to change the font of icons present on Moodle according to the need of their organization and users.

\section{CONCLUSION}


On the basis of above-mentioned study, it is very clear that it clearly depends upon the requirements which learning management system one wants to use, which version suits their requirements at fullest. After above conducted study helped us choose Moodle 3.2 as it has added features like text auto-save, likes, ratings, dashboard, view grades in one precise screen, new test types, online recycle bin, support for office converter, grading improvements, auto-login, sign up improvements, preferences. Above mentioned features clearly fulfill requirements of our institute so we choose Moodle version 3.2. 


\section{REFERENCES}

[1] LMS Definition available at: Dar es Salaam. Library Hi Tech News http://www.nationaltrainingsoftware.com/l incorporating online and CD notes. msdefinition.html. [Online]. 21. pp. 227-239.

[2] K. S. Hong, A. A. Ridzuan, and M. K. [7] Ugur Demiray, Cases on Challenges Kuek. (2003). Students' attitudes toward the facing e-Learning and National use of the Internet for learning: A study at a development: Institutional Studies and university in Malaysia. Educational Technology and Society. [Online].

[3] Ellis, Ryann K, Field Guide to Learning Management Systems, ASTD Learning Circuits, (2009), http://www.astd.org/NR/rdonlyres/12ECD B99-3B91-403E9B157E597444645D/23395/LMS_fieldguide_2 0091.pdf. Practices, Vol II, Anadolu University, Turkey, p603

[8] E. W. Nwagwu, J. Adekannbi, and O. Bello. (2009). Factors influencing use of the Internet: A questionnaire survey of the students of University of Ibadan, Nigeria. The electronic library. [Online]. 27. pp. 718-734.

[9] Bret Hall, e-Learning - Applying

[4] M. Madhusudhan. (2007). Internet use by research scholars in University of Delhi, India. Library Hi Tech News. [Online]. 8. pp. 36-42.

[5] Rosalina Babo, and Ana Azevedo, "Higher Education Institutions and Learning Management Systems: Adoption [6] I. Luambano and J. Nawe. (2004). Internet use by students of the University of Technology to Education. Digital Oman, issue 32005 , available at http://www.digitaloman.com/indexead5.ht ml ?issue $=3 \&$ lang $=\quad$ en\&id $=14 \_1 . \quad$ [7] Report available at: http://main.omanobserver.om/node/53947 (News on Oman Observer, 7th June 2011). [10] K. O. Jagboro, "A study of internet usage in Nigerian 